\title{
Spores and Pollen Colour Changes and Thermal Maturation of Mid-Cretaceous Lacustrine Organic-rich Sediments in the Mamfe Basin, S.W. Cameroon
}

\author{
Njoh Olivier A. ${ }^{1} \&$ Tembi Atud ${ }^{2}$ \\ ${ }^{1}$ Department of Geology, Mining and Environmental Science, Faculty of Science, University of Bamenda, \\ Cameroon \\ ${ }^{2}$ Department of Geology, Faculty of Science, University of Buea, Cameroon \\ Correspondence: Njoh Olivier A. Department of Geology, Mining and Environmental Science, Faculty of \\ Science, University of Bamenda, Cameroon. Tel: 237-677-243-971. E-mail: njoh68@yahoo.fr
}

\author{
Received: November8, 2017 Accepted: December 18, 2017 Online Published: December 25, 2017 \\ doi:10.5539/jgg.v10n1p22 URL: http://dx.doi.org/10.5539/jgg.v10n1p22
}

\begin{abstract}
Repeated palynological analyses of samples collected from lacustrine black organic rich shales and carbonate rocks which are abound in the Mamfe Basin have consistently yielded extremely low count of palynomorphs. Geochemical analysis of the same rocks revealed very high Total Organic Carbon (TOC) content of up to $16.10 \mathrm{wt} \%$, whereas similar rocks elsewhere as expected, yielded high abundance and diversity of palynomorphs. Several geologic factors involved in the burial history of sedimentary rocks may account for this low sporomorphs count, however, microscopic analyses of the changes in their colour, provides a quick and relatively cheap approach by which the thermal alteration of the sediments can be reconstructed. Palynomorphs data from this and previous studies of the same sediments were compared and confirmed to be very poor in abundance however, the few recognizable species undoubtedly permitted the assignment of an Albian-Turonian age to these sediments under study. Spore-pollen colour variation (Munsell colour standards) has proven to have a positive correlation with thermal alteration hence, sediments and organic matter maturation. Using a three sporomorph group (SG) that include: (1) leiotrilete spores of the genera Cyathidites, Deltoidospora, Dictyophyllidites, Gleicheniidites, and Leiotriletes (SG-1) with sporoderm thicknesses $<1 \mu \mathrm{m}, 1-1.5 \mu \mathrm{m}$ and $>1.5 \mu \mathrm{m}$, respectively); (2) trilete, regulate spores of the genus Lycopodiacidites (SG-2); (3) trilete, striate spores of the genus Cicatricosisporites (SG-3); and (4) the gymnosperm-pollen taxon Classopollis torosus (SG-4). Results show here that the colour index varied from 2.5 to 5.0, indicating low to high maturity with Kerogen types I, II and III corresponding to a paloetemparature range of 60 to $140^{\circ} \mathrm{C}$ for an estimated stratigraphic interval of 1000 to $3000 \mathrm{~m}$ in the Mamfe Basin.
\end{abstract}

Keywords: alteration, lacustrine, maturation, paleotemperature, palynomorphs, sporomorph group

\section{Introduction}

The investigation of the extent of thermal maturation of an identified source rock unit in a prospective basin such as the Mamfe Basin is essential to the evaluation or prediction of its petroleum potentials. Several maturation parameters of potential source rocks units are known and have been used. Selly, (1985) in Al-Mashramah, (2011) grouped these parameters into two categories; chemical paleothermometers and biological paleothermometers. While the chemical paleothermometers include the study of both organic and inorganic matter, biological paleothermometers are largely based on the monitoring of the changes in colour, an optical properties of fossilized pollen and spores (Al-Mashramah, 2011) as have been used in the present study of the black organic-rich shales of the Mamfe Basin. Other organic fossils include; Graptolites, archritarch, scolecodonts and conodonts. Fossilized pollen and spores have and organic cell wall (organic composition) and Marshall (1990) noted that, following the increase in burial depth and consequently temperature, the organic matter in the sediments alters progressively as hydrogen and oxygen are lost in excess of carbon (Al-Mashramah, 2011). It is on this basis that sporomorphs provide a reliable alternative method for establishing thermal maturation of sediments based on its temperature-dependent colour changes and is consequently invaluable in the prediction of the hydrocarbon window. Sporomorph colours change from pale yellow to orange and brown to opaque with 
increasing thermal maturity. This colourimetric evolution is progressive, cumulative and irreversible (Correia, 1971; Yule et al., 1998). These temperature-dependent colour variations are particularly sensitive in the lower range of thermal maturation where they can yield more precise information than vitrinite reflectance.

Black organic rich fine-grained sedimentary rocks are abound and well exposed at several localities in the Mamfe Basin and those outcropping in the eastern part of the basin were sampled for the present work (Fig. 1). They occur usually as very thick shales or carbonaceous beds, frequently inter-bedded by calcareous and sandstone beds (Njoh et al., 2015; Eyong et al., 2013; Abolo, 2008).

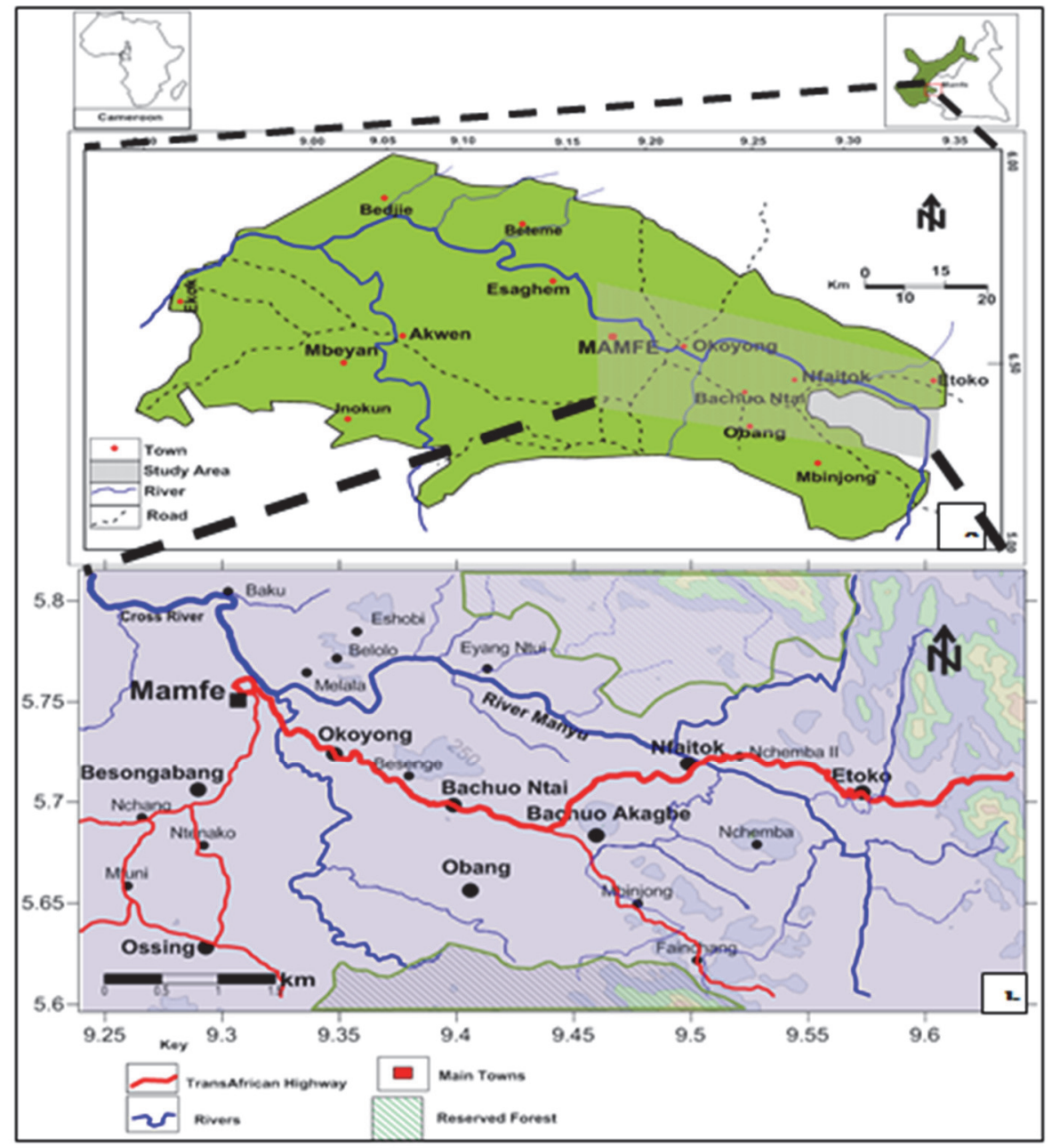

Figure 1. Location map of the study are in the easterm part of the Mam fe Basin

Studies of the sediments of this basin have generally been timid and those specifically focused on source rock evaluation have just began (Njoh and Mesanga, 2016; Esseme, 2010). Njoh et al. (2015) and Abolo (2008) noted that these predominantly shaly lithologic strata are of Mid-Cretaceous age and belong to the middle Nfaitok Formation of the three units that make up the lithostratigraphic succession in the Mamfe Basin.

Repeated palynological studies of several samples collected from different parts of this unit have consistently yielded very poor counts of pollen and spores (Tembi, 2015; Njoh et al., 2015; Nana, 2014). Njoh and Mesanga (2016) reported Total Organic Carbon content (TOC) as ranging from $1.06 \mathrm{wt} \%$ to very excellent amounts of $16.10 \mathrm{wt} \%$ from various strata and locations of this sedimentary unit. Excellent TOC values obviously mean high amounts of organic matter with a corresponding high yield of pollen and spores in these sediments. These values that reveal very high amounts of preserved organic matter and thus good to excellent quality (Kerogen type I, II and III) that can generate both oil and gas (Njoh and Mesanga 2016).Contrarily to our expectations these sediments yielded very low sporomorph counts. In addition, many forms recovered were at various degrees of degradation, probably from poor preservation or progressive thermal alteration and so were unidentifiable. 
Holding the assumption for now that the very poor sporomorphs yields are due to thermal degradation, the present study has therefore taken the advantage of colour changes observed in the palynomorphs obtained from these sediments to assess the extent to which they have been thermally altered and to estimate the temperature at which some of these sediments attained the oil window. To do this, we compared our sporomorphs data with and guided by the methods outlined in Pross et al.(2007) to show that this method is applicable as it corroborates with calculated Vitrinite Reflectance from Rock-Eval Pyrolysis analyses carried earlier on these sediments.

\section{Geologic Setting}

The Mamfe Basin is a near elliptically-shaped rift-splay basin that bifurcates off the Benue Trough and trends WNW-ESE for $130 \mathrm{~km}$ into Cameroon (Eyong et al., 2013). The surface area is estimated to measure about $2400 \mathrm{~km}^{2}$ (Le Fur, 1965; Dumort, 1968; Eyong et al., 2013). The basin has a length of about $130 \mathrm{~km}$ and a width of $60 \mathrm{~km}$ and it has an almost E-W trending orientation (Le Fur, 1965; Dumort, 1968). Administratively, the Mamfe Basin is located in Manyu Division of the Southwest Region of Cameroon (Njoh et al., 2016). It is bordered to the north by the Precambrian rocks of the Obudu Massif, in the south by the Oban Massif Precambrian Basement Complex which separates it from the Rio del Rey Basin, to the west the Mamfe Basin is open and continues as a part of south-eastern Benue Trough of Nigeria and it narrows and terminates under the Cameroon Volcanic Line (CVL) in the east and northeast (Njoh et al., 2016) (Fig.2).

Petters, et al., 1987, described the Mamfe Basin as a half graben rift system that straddles the borders of Cameroon into Nigeria where it is referred to as the Mamfe Embayment. As an arm of the Benue Trough, this basin is equally linked to the WCARS and is closely associated with the opening of the South Atlantic Ocean (Njoh et al., 2016). Hence, like other basins of the sub-region, Mamfe Basin is formed as a result of the Gondwana break-up and the resultant separation of South America from the African continent (Njoh et al., 2016).

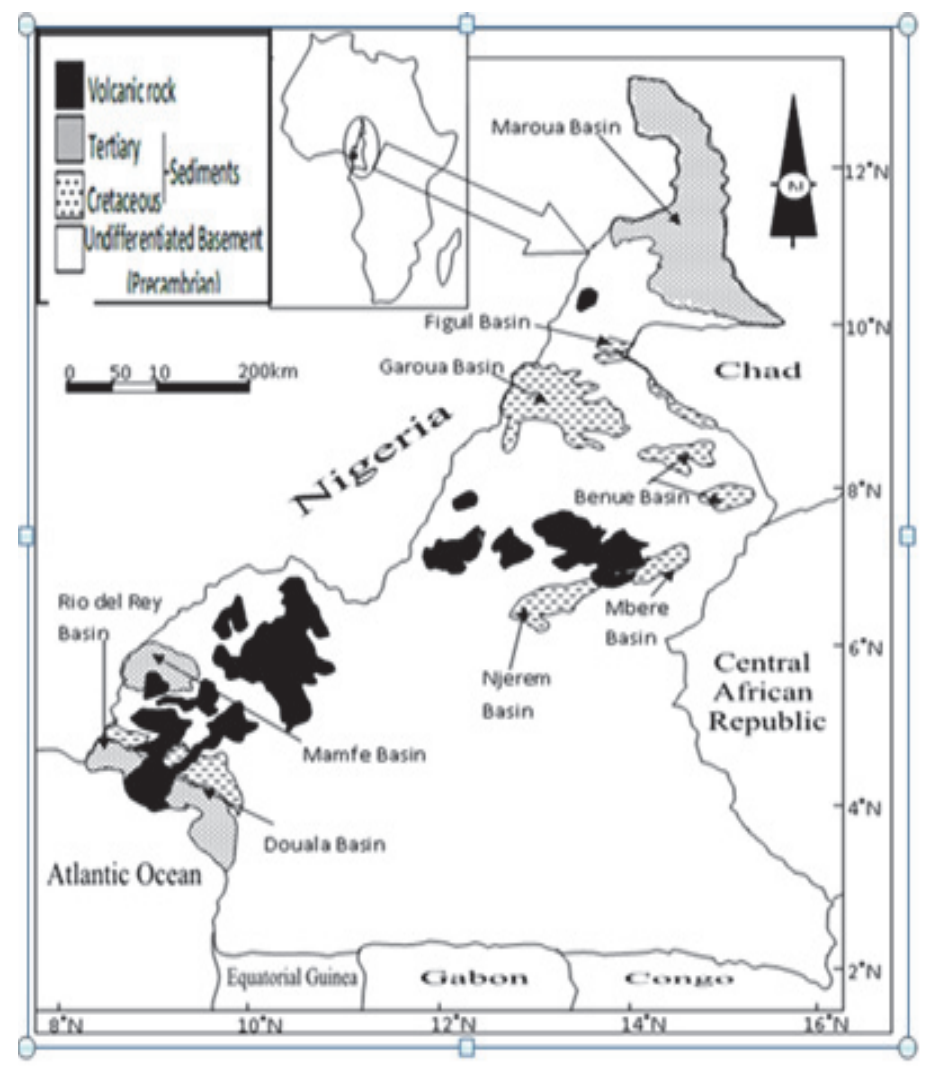

Figure 2. Map of Cameroon showing the Mamfe and Garoua Basin among other sedimentary basins in Cameroon (Adopted rom Njoh and Mesanga, 2016)

\section{Stratigraphic Framework}

Wilson, (1928), Le Fur, (1965), Dumort, (1978), Petters, (1978), Abolo, (2008) and Njoh et al.(2015) are amongst the several authors who have published their findings on the stratigraphic framework of the Mamfe 
Basin. Njoh et al. (2015) evidently noted the gross inconsistencies and discrepancies in the manner in which most of the previous publications presented the stratigraphic framework of the basin. These include amongst others, Le Fur, (1965) who recognized and sub-divided the rocks into five units which he called Series (C1-C5 from top to bottom respectively); IRGM/DYU1 (2000) recognized only three unites that were later on supported by Abolo, (2008) who sub-divided the entire Mamfe Basin into a single formation (Mamfe Formation) made up of three members.For the purpose of this work, the stratigraphic framework proposed by Abolo, (2008) will be adopted in the mean time.

As it is known for now, the stratigraphic frameworks of the Mamfe Basin points to three fundamental stratigraphic units (formations or members) which comprises a lower alluvial fan conglomerate and a fluvial channel cross bedded conglomeratic sandstone sequence, a middle predominantly repeated sequence of alternating black shales, limestones, sandstones and evaporites of lacustrine paleoenvironment and an upper deltaic-fluvial sandstone unit (Fig 3).

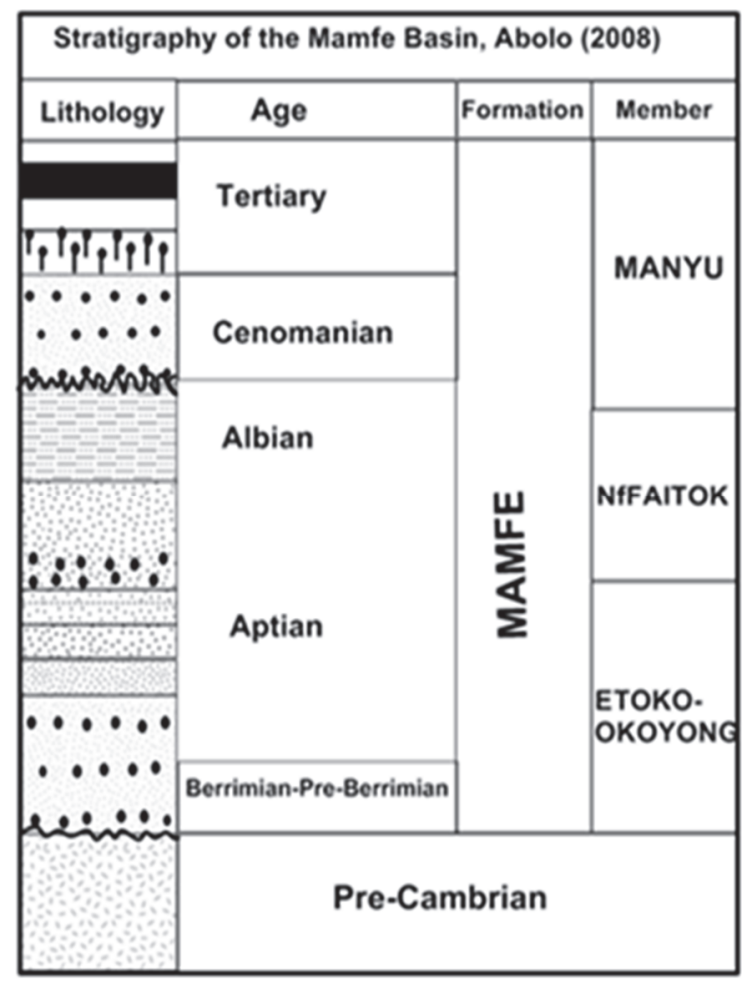

Figure 3. Stratigraphy o the Mamfe Basin (Abolo, 2008) showing three members of the lone Mamfe formation lying on the Pre-Cambrian basement rocks

\section{Material and Methods}

\subsection{Palynology}

Twenty-nine samples from roadside-cuts and river bank outcrops representing the Nfaitok Member (eastern part of the Mamfe Basin) were collected and analyzed for their palynomorph content following standard palynological techniques (Herngreen et al., 1976; Burger, 1980; Riding and Kyffin-Hughes, 2004 and Riding et al., 2007). Visual colour analysis were later carried out on the sporomorphs recovered based on a visual comparison with the Munsell colour standards as suggested by Pearson (1984) in Pross et al., (2007).

The samples were dried at temperatures between $50^{\circ}$ to $70^{\circ}$ in an electric oven for a few hours. $25 \mathrm{~g}$ of each sample was collected and weighed using an electronic balance. Treatment of crushed samples with $\mathrm{HCl}(10 \%)$ and $\mathrm{HF}$ (40\%) was carried out at high temperature to ensure the removal of carbonates and silicates respectively. Following each treatment with $\mathrm{HCl}$ and $\mathrm{HF}$, the samples were then decanted by washing thoroughly with distilled water respectively. Subsequent to each chemical preparation step, the residues were sieved through a $6 \mu$ mylon mesh using distilled water. To avoid processing-induced bleaching of the sporomorphs, no oxidation was performed (Pross et al.,2007). If large amounts of clay minerals were present, sieving and separation in $\mathrm{ZnBr}$ was 
undertaken. Residues were subsequently sieved and divided into fractions $15-100 \mathrm{pm}$ and $>100 \mathrm{pm}$ (Herngreen et al., 1976); Burger, 1980; Riding and Kyffin-Hughes, 2004 and Riding et al., 2007).

From the analysis made, four sporomorph groups have been established based on the demonstration in Pross et al. (2007). The representative sporomorphs in each group comprised stratigraphically long ranging forms that occurred in high numbers, with high consistency in the samples and are morphologically closely related (similar sporoderm thickness) taxa. This is to minimize very wide colour variations in order to obtain strong correlation with geochemical data and a high degree of fidelity in deciphering thermal alteration. Sporomorph Group 1 (SG 1) consists of the genera Biretisporites, Cyathidites, Deltoidospora, Dictophyllidites and Gleicheniidites. Based on sporoderm thicknesses, this group is subdivided into subgroups. Subgroup 1a (SG-1a) comprises specimens with sporoderm thicknesses $<1 \mu \mathrm{m}$, Subgroup $1 \mathrm{~b}$ (SG-1b) comprises specimens with sporoderm thicknesses of 1 to $1.5 \mu \mathrm{m}$, and Subgroup 1c (SG-1c) comprises specimens with sporoderm thicknesses $>1.5 \mu \mathrm{m}$. Sporomorph Group 2 (SG 2) was defined by the genera Camerozonosporites and Lycopodiacidites meanwhile Sporomorph Group 3 (SG-3) consists of the genera Appendicisporites, Cicatricosisporites and Plicatella. Sporomorph Group 4 (SG-4) consists of the gymnosperm-pollen taxon Classopollis torosus.

\subsection{Spore and Pollen Colour Change}

Thermal maturation index is determined through microscopic examination of spore and pollen colour alterations. Spore and pollen colour index is easily marched with vitrinite reflectance which over the years has been the most popular method used for determining degree of thermal maturity. Spores and pollen experience both chemical alterations and physical alterations as a result of increased temperature which leads to colour changes (Marshall, 1991). The degree of colour change is influenced by temperature, burial depth and time.

Strew mounts of each sample were investigated under transmitted light for the representatives of each sporomorph group defined above using an Olympus BX 50 light microscope. The spore and pollen colours were estimated on the recovered forms of the four groups mentioned above based on a visual comparison with theMunsell colour standards (Table.1) as described in Pross et al.,2007.

Ujiie, (2001) described two microscopic methods used in measuring TAI of spores and pollen. This simply involves (I) to simply distinguish their morphology and colours by using the eyes (II) to simply establish the translucency of the organic matter by using photoelectric measurements.

Colour change assessment can be generally difficult because the colour varies widely within a single sporomorph assemblage. These variation are influenced by (I) wall thickness (II) variation in composition (III) degree of oxidation and degradation (IV) presence of reworked and curved samples (El Beialy et al., 2010).

The Spore Colour Index (SCI) ranges from 1 to 10 (Table 1) and reflects a colour gradation from colourless or pale yellow to black (Marshall 1990; Utting and Hamblin 1991; Table 1). The TAI is assessed from the colour of spores and pollen before oxidation treatment of the samples, and by using a five point scale (Marshall, 1990; Utting and Hamblin1991; Table2).

Table 1. Colour changes in spores and pollen, and Spore Colour index (SCI). Modified from Marshall (1990)

\begin{tabular}{|l|l|}
\hline Spores colour & $\mathrm{SCl}$ \\
\hline Pale yellow & 1 \\
\hline Pale yellow- lemon yellow & 2 \\
\hline Lemon yellow & 3 \\
\hline Golden yellow & 4 \\
\hline Yellow orange & 5 \\
\hline Orange & 6 \\
\hline Orange brown & 7 \\
\hline Dark brown & 8 \\
\hline Dark brown- black & 9 \\
\hline black & 10 \\
\hline
\end{tabular}


Table 2. Parameters for measuring maturation (modified from Mehrotra et al., 2015)

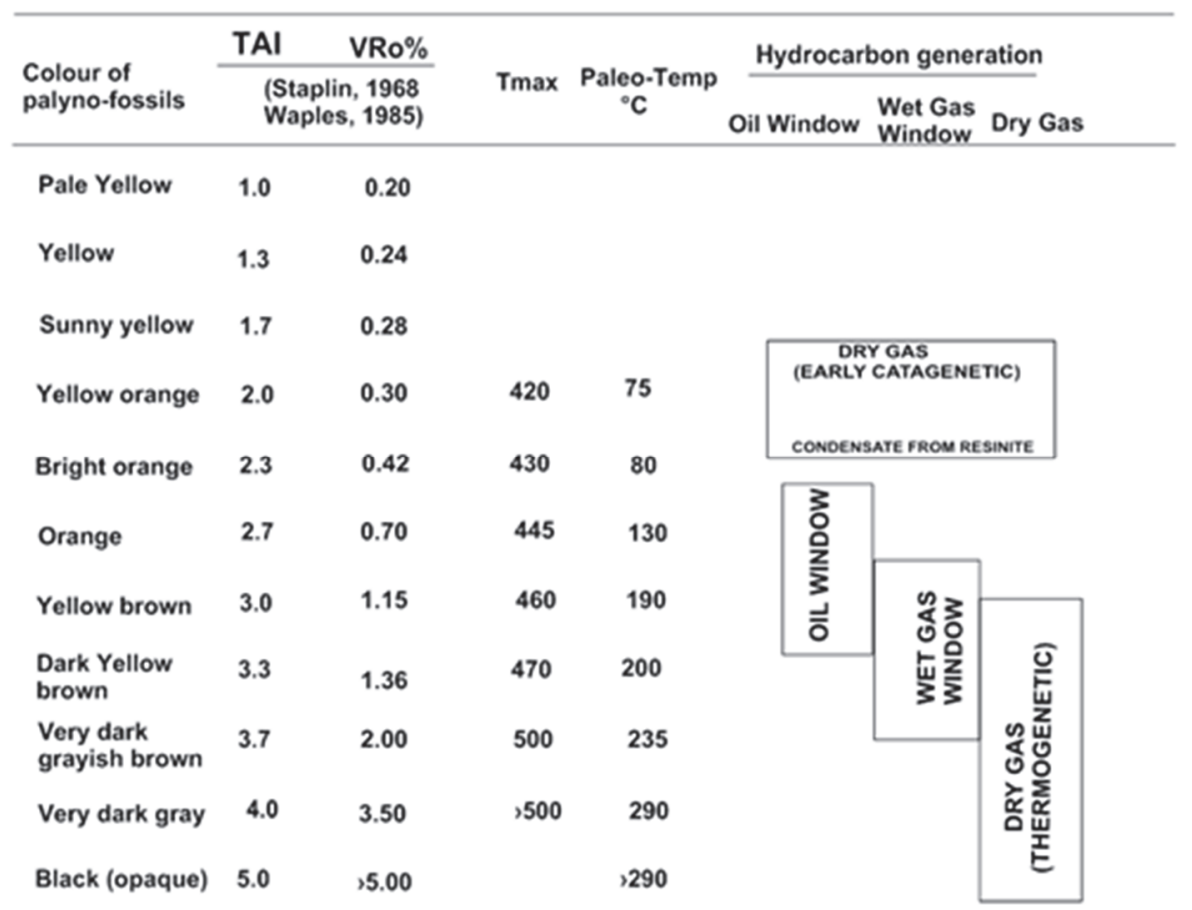

A transparent and pale yellow colourindicates TAI 1, medium orange TAI 2, dark brown TAI 3, black TAI 4, and vitreous black and brittle spores and pollen indicate TAI 5 (Utting and Hamblin 1991), (Table. 3)

Table 3. Correlation between colour changes in spores and pollen, Thermal Alteration Index (TAL) and hydrocarbon generation zones. Based on Marshall (1990, fig. 2) and (Utting \& Hamblin 1991).

\begin{tabular}{|l|l|l|}
\hline Spores and pollen colour & $\begin{array}{l}\text { Thermal alteration } \\
\text { index (TAI) }\end{array}$ & Petroleum generation \\
\hline Pale yellow- yellow & 1 & Immature Kerogen \\
\hline $\begin{array}{l}\text { Yellow to light orange - medium } \\
\text { orange }\end{array}$ & 2 & Oil window \\
\hline Dark brown & 3 & Gas window \\
\hline Brownish black to black colour & 4 & $\begin{array}{l}\text { wet gas limit - dry gas } \\
\text { preservation }\end{array}$ \\
\hline Vitreous black- fossils brittle & 5 & Dry gas preservation limit \\
\hline
\end{tabular}

\section{Results}

\subsection{Palynology}

A number of the samples studied were palynoferous, some yielded palynomorphs in subordinate amounts while others yielded practically no palynomorphs (PNP). Thirty nine palyno-taxa were recovered but their identification down to species level was hindered due probably due to poor preservation (Njoh et al., 2015). In addition long-ranging forms were common with a few diagnostic forms (Table 4). The palynomorphs were placed into four groups including, pteridophytic spores, gymnosperm angiosperm pollen and fungal spores, archritarch and they showed a predominance of sporomorphs.

The sporomorphs recovered from the Mamfe Basin are dominated by spores of pteridophytes and subordinately gymnosperm pollen grains. While Cicatricosisporites dominates the spores, Ephedripites and Classopollis are major components of the pollen grains. A few fungal spores and archritarch are common in most of the samples. 
The diversity and preservation of the sporomorphs are generally poor (Fig 3).

At the Nfaitok outcrop, Cicatricosisporites $s p$. and Classopollis sp. were recognized as the marker forms. Both forms generally range in age from Aptian-Turonian and have aided the recognition of sediments this age elsewhere. Morphologically simple genera Biretisporites, Cyathidites, Deltoidospora, Dictyophyllidites, Gleicheniidites, and Leiotriletes are which were recovered and easily identified, offered the credible potential for thermal evaluation carried out as proven by Pross et al. (2007).

Table 4. List of palynomorphs recovered from analysis: pteridophytes, angiosperms/gymnosperms, dinoflagellete and fungal

\begin{tabular}{|c|c|c|c|}
\hline SN & TAXA & Count & Percentage(\%) \\
\hline \multirow[t]{12}{*}{ I } & PTERIDOPHYTE SPORES & & \\
\hline & Cyathidites sp. & 12 & \\
\hline & Cicatricosisporites sp. & 15 & \\
\hline & Cingulatisporites ornatus & 3 & \\
\hline & Gleicheniidites senonicus. & 4 & \\
\hline & Echitriletes sp & 1 & \\
\hline & Cicatricosisporites cf. minutaestriatus & 7 & \\
\hline & Deltoidospora mosozoica & 1 & \\
\hline & Dictophyliidites harrisi & 7 & \\
\hline & Circulina parva & 1 & \\
\hline & Selaginella myosurus & 1 & \\
\hline & Total & 52 & 22.01 \\
\hline \multirow[t]{12}{*}{ II } & GYMNOSPERM /ANGIOSPERM POLLEN & & \\
\hline & Ephedripites sp. & 2 & \\
\hline & Psilatricolporites $s p$. & 9 & \\
\hline & Ephedripites jansoni & 1 & \\
\hline & Monocolpopollenites spheroidites & 2 & \\
\hline & Multiporopollenites $s p$ & 3 & \\
\hline & Multiporropollenites polygonals & 3 & \\
\hline & Ephedripites procerus & 2 & \\
\hline & Trichotomosulcites sp. & 2 & \\
\hline & Tubistepahanocolpites cylindricus & 3 & \\
\hline & Retitricolpites & & \\
\hline & Total & 27 & 12.91 \\
\hline \multirow[t]{2}{*}{ III } & DINOFLAGELLETE & & \\
\hline & Dinocyst indeterminate & $\mathbf{l}$ & 0.47 \\
\hline \multirow[t]{2}{*}{ IV } & OTHERS & & \\
\hline & Fungal spores & 8 & 3.82 \\
\hline & & & \\
\hline
\end{tabular}

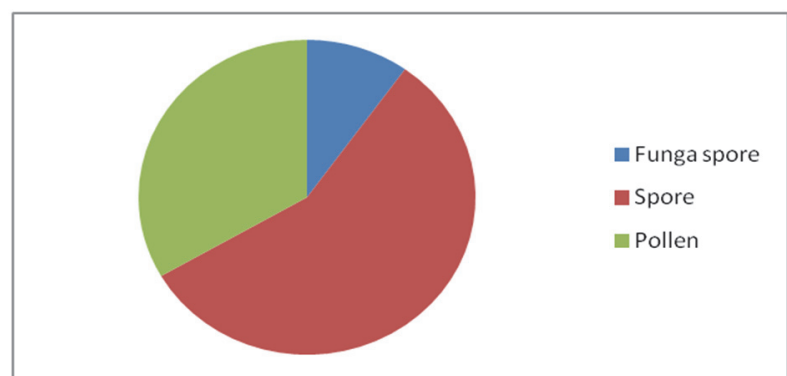

Figure 4. Proportion of palynomorphs recovered from fine grained rocks from some outcrops in the Southeastern Mamfe Basin 


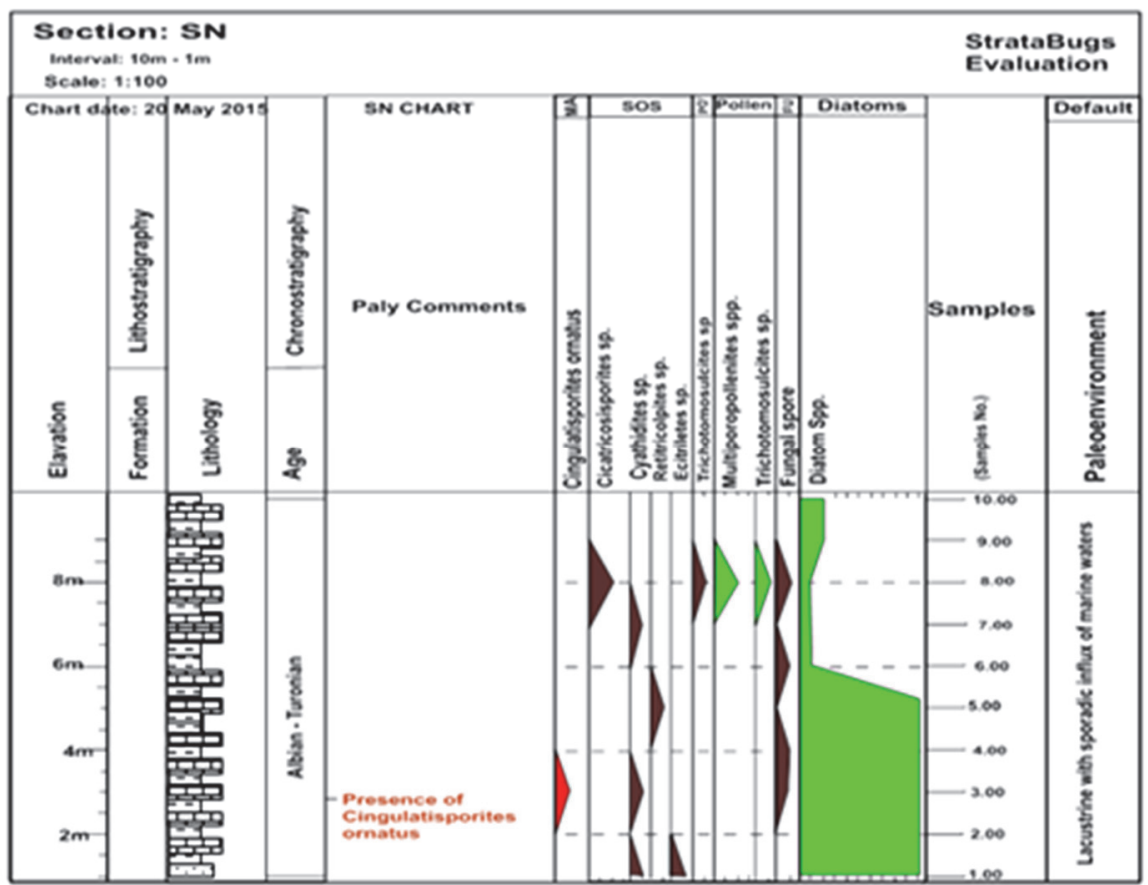

Figure 5. Palynostratigraphical distribution chart for Nfaitok

Sporomorph group 1 which consist of leiotrilete spores of the genera Biretisporites, Cyathidites, Deltoidospora, Dictyophyllidites, Gleicheniidites, and Leiotriletes was separated into three subgroups (SG-1a, SG-1b and SG-1c ) based on sporoderm thickness $(<1 \mu \mathrm{m}, 1$ and $1.5 \mu$ mand $>1.5 \mu \mathrm{m}$ respectively) are present in a number of the palynoferous samples investigated.

SG-2, i.e., trilete spores of the genera Camerozonosporites and Lycopodiacidites, are relatively rare within the sample series. This group exhibits the most irregular pattern of all sporomorphgroups. These forms were recovered in the samples from the lower part of the section.

SG-3, consisting of striate trilete spores of the genera Appendicisporites, and Cicatricosisporites were recovered in the samples from the lower part of the section with count ranging from 2-6.

SG-4, consisting of Classopolis torosus was found in a good number of samples, except those at the top of the section. The TAI values estimated for SG-4 yield the mostconsistent of all examined sporomorph groups.

\subsection{Thermal Maturation}

Organic materials in sedimentary rocks in general are said to be composed of soluble organic matter and kerogen. At moderate degree of maturation the sapropelic materials and sporonite of kerogen can be converted to liquid hydrocarbons, while the vitrinite can produce dry gas. Spores and pollen are the important components of organic materials in sedimentary rocks and are also the highly productive oil-precursors. Colour changes of palynomorphs are extremely useful in determining the thermal maturation history of the sediments and fossils (Staplin, 1969 and Battern, 1982 in Pross et al., 2007). Zhao (1984) noted that the degree of maturation of organic matter, oil generation and evolution can be extrapolated from sporomorph colour changes and degree of thermal alteration of spores and pollen grains recovered from sedimentary rocks.

Therefore sporomorph colour index can be used in conjunction with vitrinite reflectance to determine thermal maturation (Zhao 1984). Thermal maturity is a key parameter for the determination of potentially prospective shale oil and gas accumulations at initial stages of exploration. Based on thermal maturity values, source rocks are categorized as thermally immature, mature or post-mature rocks in terms of capability to generate hydrocarbons. Thus, fossil specimens of long-ranging taxa, such as Biretisporites, Cyathidites, and Cocavisporites, with a lustrous pale yellow colour indicate a thermally immature zone (El Beialy et al. 2010). As a response to increasing temperatures spores and pollen will change from yellow to medium orange (TAI 2), indicating the later stage of diagenesis and the beginning of the oil window. TAI 2 as observed in the samples from the upper part of the section is roughly equivalent to vitrinite reflectance $\% \circ=0.5$ and CAI 1.5 , suggesting 
temperatures more than $60^{\circ} \mathrm{C}$ (Zhao, 1984; Marshall, 1990; Pross et al., 2007; El Bailey et al., 2010). TAI 2+ indicates the peak of wet gas generation. With increasing temperatures the TAI increase to 3 and the spores and pollen have a dark brown colour, indicating the oil "death" line and the peak of the dry gas generation in terms of petroleum zones (Zhao, 1984; Marshall, 1990; Pross et al., 2007; El Bailey et al., 2010). In addition, TAI 3 which was observed in the samples from the lower section of the section is approximately equivalent to vitrinite reflectance $\% \mathrm{R}^{\circ}=1.20$ and $\mathrm{CAI}=2$, suggesting the catagenetic stage and temperatures more than $120^{\circ} \mathrm{C}$.

\section{Discussion and Conclusion}

Based on the semi-quantitative assessment of Cretaceous sediments in the Nfaitok Member of the Mamfe Basin, by carrying out estimates through the visual comparison of sporomorph colours to Munsell colour standards in conjunction with vitrinite reflectance and T.O.C values from Njoh and Mesanga (2016) the following conclusions were arrived at

1. Estimates of sporomorph colours using Munsell colour standards under defined, constant optical conditions yielded a range of spore and pollen grain colours which include yellow orange, yellow brown, dark yellow brown, dark gray to black.These colours are dependent on taxonomically related long-ranging sporomorphs with similar sporoderm thicknessesand indicate that different sporomorph groups yield varying degrees of fidelity withrespect to deciphering thermal alteration.

2. SG-1; consisting of Biretisporites, Cyathidites, Deltoidospora, Dictyophyllidites, Gleicheniidites and Leiotriletes), Sporomorph Group 4 (SG-4; Classopollis torosus), and Sporomorph Group 3 (SG-3; Appendicisporites, and Cicatricosisporites) yielded the clearest thermal alteration data. Meanwhile SG-1 which was separated into subgroups based on sporoderm thickness reveal that forms with similar sporoderm thickness show reliable trend between the colour change and vitrinite reflectance.

3. Contrary to an expected down section increase in thermal alteration, in correlation with vitrinite reflectance, the TAI data show a narrow trend towards greater maturity throughout most of the lower part of the section. Highest TAI values tend to occur in representatives of sporomorph groups SG-2 and SG-3. This pattern indicates that within sporomorph group SG-1 representatives of subgroup SG-1a are primarily slightly lighter than representatives of the subgroups SG-1b and especially SG-1c. In turn, representatives of sporomorph groups SG-2 and SG-3 are primarily slightly darker than representatives of sporomorph group SG-1.

4. The C.A.I and the T.A.I in conjunction with corresponding vitrinite reflectance values and T.O.C values from Marshall (1990); Utting and Hamblin (1991); Table 1 revealthat the source rocks of the Nfaitok Member of theMamfe Basin are immature to very mature occurring within the wet gas and dry gas limit of hydrocarbon production. Though poor in sporomorph content, show indications of organicmatterthatisgoodtoexcellentqualitywith Kerogen typeI andII as the main organic matter type present.Type I and II kerogen generate most of the world's oil when subjected to burial temperatures between $60^{\circ} \mathrm{C}$ and $160^{\circ} \mathrm{C}$.

\section{Acknowledgement}

The authors dully acknowledge and appreciate Mrs Essien and laboratory technicians of South Sea Petroleum Company Nigeria, who assisted enormously during the processing of the samples used in this work and Njie Sara who provided geochemical data (vitrinite reflectance and T.O.C values) for correlation and who also accompanied us during the field phase of this work.

\section{References}

Abolo, M. G. (2008). Geology and petroleum potential of the Mamfe basin, Cameroon, central Africa. Africa Geoscience Review, Special Publication 01 \& 02, p.65-77.

Ajonina, H. N., \& Bassey, C. E. (1997). Stratigraphy and depositional environments of the Mamfe formation and its implication on the tectono-sedimentary evolution of the Ikom-Mamfe embayment. In: 15th Annual International Conference and Exhibition Book of Abstracts and Programme. Nigerian Association of the Petroleum Exploration (NAPE), 39p.

Ajonina, H. N., Ajibola, O. A., \&Bassey, E. C. (2001). The Mamfe basin, SE Nigeria and SW Cameroon: A review of the basin filling model and tectonic evolution. Journal of the Geoscience Society of Cameroon, $1(1), 24-25$.

Al-Mashramah, Y. A. A. (2011). Maturity of kerogen, petroleum generation and the application of fossils and organic matter for paleotemperature measurements. Examensarbeten i geologi vid Lundsuniversitet, $\mathrm{Nr} 274$, 
$30 \mathrm{pp}$.

Atta-Peters, D., Agamac, I., Asiedu, D. K., \& Apesegah, E. (2013). Palynology, palynofacies and palaeoenvironments of sedimentary organic matter from Bonyere-1 Well, Tano basin, western Ghana. International Letters of Natural Sciences, 5,27-45.

Baker, L. L., Bernard, A., Rember, W. C., Milazzo, M., Dundas, C., Abramov, O., \& Keszthelyi, L. (2015). Temperature profile around a basaltic sill intruded into wet sediments. Journal of Volcanology and Geothermal Research, 302, 81-86.

Barker, C. E. (1996). A comparison of vitrinite reflectance measurements made on whole-rock and dispersed organic matter concentratemounts. Org. Geochem., 24, 251-256.

Burger, D. (1980). Palynological studies in the Lower Cretaceous of the Surat Basin, Australia. Bulletin 189. Bureau of Mineral Resources, Geology and Geophysics, Canberra.

Christopher, R. A., \&Prowell, D. C. (2010). A palynological biozonation for the uppermost Santonian and Campanian Stages (Upper Cretaceous) of South Carolina, USA. Cretaceous Research, 31, 101-129.

Eseme E., Littke, R., \& Agyingi, C. M. (2006). Geochemical characterization of Cretaceous black shale from the Mamfe Basin, Cameroon. Petroleum Geoscience, 12, 69-74.

Eyong, J. T., Wignall, P., Fantong, W. Y., Best, J., \& Hell, J. V. (2013). Paragenetic sequences of carbonate and sulphide minerals of the Mamfe Basin (Cameroon): Indicators of palaeo-fluids, palaeo-oxygen levels anddiagenetic zones. Journal of African Earth Sciences, 86, 25-44.

Gutjahr, C. C. M. (1960). Palynology and its Application in Petroleum Exploration. Gulf Coast Association of Geological Societies Transactions, 10, 175-188.

Herngreen, G. F. W., \& Chlonova, A. F. (1981). Cretaceous Microfloral Provinces. Pollen et Spores, 23, 441-557.

Herngreen. G. F. W. (1976). Microflora of Africa and South America and Upper Cretaceous. International Palynology Conference, p. 66-77.

Lashin, G. M. A. (2007). Palynostratigraphic studies of Cretaceous sediments Alamein Formation, Bahrein-1 well in the Northern part of the Western Desert, Egypt. Journal of Applied Science, 7(9), 1304-1313.

Lawal, O., \& Moullade, M. (1986). Palynological biostratigraphy of the Creteceous sediments in the Upper Benue Basin, N.E. Nigeria. Revue de Micropaleontologie, 29, 61-83.

Marshall, J. E. A. (1990). Determination of thermal maturity. In Briggs, D.E.G. and Crowther, P. (eds): Palaeobiology - a synthesis, 511-515. Blackwell Scientific Publications, Oxford, UK.

Miall, A. D. (2000). Principles of Sedimentary Basin Analysis. 3rd and Enlarged Edition, Springer-Verlag, Berlin, $616 \mathrm{p}$.

Micheal, I. O., Charlse, I. U., \& Efosa, U. (2016). The use of jointing to infer deformation episodes and relative ages of minor Cretaceous intrusives in the western part Ikom - Mamfe Basin, southeastern Nigeria. Journal of African Earth Sciences.

Nguimbous-Kouoh, J. J., Takougang, E. M. T., Nouayou, Tabod, T. C., \& Manguelle-Dicoum, E. (2012). Department of structural Interpretation of the Mamfe sedimentary basin of Southwestern Cameroon along the Manyu River using audiomagnetotellurics survey. International Scholarly Research Network ISRN Geophysics Volume, 2012, Article ID 413042, 7 pages.

Njoh, O. A., \& Mesanga, N. S. (2016). Hydrocarbon Source Rock Potential of the Lacustrine Black ShaleUnit, Mamfe Basin, Cameroon, West Africa. Earth Science Research, 5(2). http://dx.doi.org/10.5539/esr.v5n2p217

Njoh, O. A., Bassey, E. A., Essien, A. J., \& Agbor, V.W. (2013b). Palynostratigraphy of Early Cretaceous Sedimentary Deposits from the Rio Del Rey Basin, S.W. Cameroon. Journal of the Cameroon Academy of Science, 13, 156-166.

Njoh, O. A., Essien, J. A., \&Tembi, A. (2014). Albian-Turonian palynomorphs from Mundeck and Logbadjeck Formations, Ediki River, north-western part of the Douala Sub-basin, Cameroon. Science, Technologies et Development, 15, 66-77.

Obi, D. A., Obi, E. O., \& Okiwelu, A. A. (2013). Basinal Configuration and Intrasediment Intrusives As Revealed by Aeromagnetics Data of South East Sector of Mamfe Basin, Nigeria. IOSR Journal of Applied Geology and Geophysics, 1(5), 1-8. 
Oboh-Ikuenobe, F. E., Obi, C. G., \& Jaramillo, C. A. (2005). Lithofacies, palynofacies, and sequence stratigraphy of Palaeogene strata in Southeastern Nigeria. Journal of African Earth Sciences, 41, 79-101.

Oboh-Ikuenobe, F. E., Yepes, O., \& Gregg, J. M. (1998). Palynostratigraphy, palynofacies and thermal maturation of Cretaceous-Paleogene sediments from the Cote D'Ivoire-Ghana transform margin. Proceedings of the Ocean Drilling Program Results, 159.

Ogala, J. E., Ola-Buraimo, A. O., \& Akaegbobi, I. M. (2009). Palynological and Palaeoenvironmental Study of the Middle-Upper Maastrichtian Mamu Coal Facies in Anambra Basin, Nigeria. World Applied Science, 7(12), (12), 1566-1575.

Ola-buraimo, A. O., \& Oluwajana, A. O. (2012). Sedimentological and Palynological Assessment of Bima Group, Bornu Basin, Northeastern Nigeria. The Pacific Journal of Science and Technology, 13(2), 297-406.

Petters S. W. (1978). Stratigraphic Evolution of the Benue Trough and its implications for the Upper Cretaceous paleogeography of West Africa. The Journal of Geology, 86(3), 311-322.

Petters, S. W., Okereke, C. S., \& Nwajide, C. S. (1987). Geology of the Mamfe Rift. In Matheis, G. \& Schandelmeier, H. (Eds.), Current Research in African Earth Sciences, Balkema, Rotterdam (pp. 299-302).

Pross, J., Pletsch, T., Shillington, D. J., Ligouis, B., Schellenberg, F., \& Kus, J. (2007). Thermal alteration of terrestrial palynomorphs in mid-Cretaceous organic-rich mudstones intruded by an igneous sill (New Foundland Margin, ODP Hole 1276A). International Journal of Coal Geology, 70(2007) 277-291.

Riding, J. B., \& Kyffin-Hughes, J. E. (2004). A review of the laboratory preparation of palynomorphs witha description of an effective non-acid technique. RevistaBrasileira de Paleontologia, 7(1), 13-44.

Schrank, E. (2010). Pollen and spores from the Tendaguru Beds, Upper Jurassic and Lower Cretaceous of southeast Tanzania: palynostratigraphical and paleoecological implications. Palynology, 34(1), 3-42.

Staplin, F. L. (1969). Sedimentary organic matter, organic metamorphism, and oil and gas occurrence. Bulletin of Canadian Petroleum Geology, 17, 47-66.

Ujiié, Y. (2001). Brightness of pollen as an indicator of thermal alteration by means of acomputer-driven image processor: Statistical thermal alteration index (TAI). Org.Geochem, 32(1), 127-141.

Utting, J., \& Hamblin, A. P. (1991). Thermal maturity of the Lower Carboniferous Horten Group, Nova Scotia. International Journal of Coal Geology, 13, 439-456.

Zhao C. (1984). Thermal alteration of spores and pollen and maturity of organic matter of the Cretaceous System Songliao basin, Northeast China. Geochemistry, 3(1).

Zhuang, M., Liming, J., Yuandong, W., \& Cong, H. (2015). Palynofacies and geochemical analysis of the Triassic Yanchang Formation, Ordos Basin: Implications for hydrocarbon generation potential and paleoenvironment of continental source rocks. International Journal of Coal Geology.

\section{Copyrights}

Copyright for this article is retained by the author(s), with first publication rights granted to the journal.

This is an open-access article distributed under the terms and conditions of the Creative Commons Attribution license (http://creativecommons.org/licenses/by/4.0/). 